Journal of Teacher Education for Sustainability, vol. 22, no. 1, pp. 37-48, 2020

\title{
Establishing Sustainable Teacher Education with Weekly School Practice - Identifying Teacher Students' Experiences of Didactic Dilemmas in the Swedish Primary School Classroom
}

\author{
Stellan Sundh \\ Uppsala University, Uppsala, Sweden
}

\begin{abstract}
Teachers face dilemmas of different kinds in their everyday practice. It is therefore essential that teacher students become aware of the dilemmas they will face in their future profession. By integrating school practice in teacher education programs, students apply theoretical knowledge to classroom situations. In a project at a Swedish university campus, the students worked as teacher candidates one day a week at different primary schools during their first semester. The purposes were to make the teacher education at the campus sustainable by attracting more students, limiting the number of dropouts and improving the quality in the education. In the present study, it is of interest to identify the didactic dilemmas teacher students experience in classrooms with 6 to 12 year-olds. By analysing the students' written reports, the results indicate that the students' identified dilemmas relate to classroom management, the lesson content and the establishing of relationships with the children.
\end{abstract}

Keywords: teacher students, didactic dilemmas, weekly school practice, primary school, Sweden

\section{Introduction}

There is a challenge for teacher education in most European countries with too few applicants. The reasons are related both to the lack of status and prestige for the teaching professions and to the teachers' working conditions. At the same time, the organization and content of the education of teachers is a current issue in media in Sweden. There are high expectations on teacher education programs, and requests can be heard for necessary revisions in teacher education curricula to make the education more sustainable. In this context, it is a matter of making it sustainable in three ways. Firstly, teacher education should be offered all over the country so that schools also in distant areas have educated teachers. Secondly, teacher education is to include central aspects of sustainable development in all courses to make it relevant to engaged future schoolteachers. Thirdly, teacher students are to be well prepared by the reality at schools so that they do not leave the 
profession in some years and this can be achieved by a combination of theoretical studies and applied ones. In a study on high school teachers' viewpoints on teachers' professional competence, the answers were analyzed by 20 curriculum experts and one of the conclusions was that internship courses could "be very helpful if implemented correctly" and then in the context of skills such as to solve conflicts, anger management, and relationship management (Ghorbani, Jafari, \& Sharifian, 2018). At the same time, results from previous studies show that teaching practicum is a stressful task for teacher students (Geng, Midford, \& Buckworth, 2015). In these discussions, there is a demand for improving the quality of the theoretical studies and increasing the proportion of the practical ones in order to prepare the students in the best way for their profession. This situation has stimulated universities and university colleges in Sweden to find ways of attracting more students to their teacher programs by offering students to work part-time at schools. Different approaches have been worked out all over the country and then in cooperation with the local authorities. An approach could be offering $75 \%$ study place at university and $50 \%$ part-time work at schools at the same time. In this model, the teacher education program is one year longer. Other approaches that have been tried include $10 \%$ or $20 \%$ work at school and full-time studies at university, which means a working day per week at schools and no lectures or seminars scheduled on that day at the universities.

Uppsala University has a separate campus on an island in the Baltic Sea: Uppsala University Campus Gotland. This campus has a profile of sustainable development and offers two primary school teacher programs. The practicums offer opportunities for teacher students to experience how sustainable development can be included in a concrete way in the planning of teaching and learning at primary schools. Thanks to a project that was planned in cooperation with the local municipality, Region Gotland, and with the first discussions starting in 2018, the teacher students who were admitted to the primary school teacher programs for $2019 / 2020$ could apply for a $20 \%$ position for their first academic year at the university. This implies that these teacher students were to combine paid work at schools one day a week with their full-time theoretical studies in various subjects in their primary school teacher education.

As part of this project, the students participated in the present study when they were to describe the didactic dilemmas they experienced. The goal of the study is to describe the types of current dilemmas that teacher students are faced with in primary schools in a region of southern Sweden. The areas of the primary schools where the students were placed could generally be described as rural districts of a lower socioeconomic level.

\section{Theoretical Perspectives}

The dilemma perspective describes the ideas about the choices and priorities that have to be dealt with in educational activities and the different inner conflicts that these choices and decisions lead to for the teacher. In didactic situations, which may be challenging and demanding, there are no evident answers how the teacher is to act. According to Flett and Wallace a dilemma is "a situation in which the participants are required to manage competing alternatives" (2005, p.190). Dilemmas are thus problems that are difficult to solve with a number of alternatives and without there being any evident consequences. 
The basic idea in working with dilemmas using a didactic perspective is studying the practice. Observations and reflections are collected from classroom situations in order to understand or define and systematically organize what is being identified. The teachers' actions are related to theories or other colleagues' experiences (Bronäs \& Runebou, 2010, p. 28). There is, thus, no rational and absolute system to refer to when there is a need to discuss how teaching and learning are to be organized and executed. Principles from observations and experiences can be identified, but these principles have to be applied to the contexts of specific teaching situations.

Having a didactic perspective implies an awareness of the complexity and the unique character of each pedagogical context. The didactic triangle and the didactic questions are helpful as tools that teacher students and teachers can use in order to understand the complexity of, for instance, the immediate reactions that are necessary for the teacher in the teaching situations and in challenges that teachers face. The didactic triangle that has its roots in German didactics can be described in various ways by including different factors, but the basic elements are the content, the teacher and the learner (Hopmann, 1997). In discussions about the didactic triangle and its usefulness, the concept can be broadened, for instance, by including more social and cultural perspectives (Schoenfeld, 2012).

Problem posing is one of the central parts in teacher's didactic competence. In teacher education, problem posing can be seen not only as an educational tool but also as a diagnostic tool (Tichá \& Hošpesová, 2013). The different options available when problems or challenges in the teaching situation occur are, thus, to be included in the didactic courses in teacher education at universities. Teacher students should identify and discuss dilemmas and challenges even at an early stage in teacher education since they are highly useful in order to develop teacher students' didactic competence.

In the present study, the teacher students were given the opportunity to observe and reflect on challenges, and at an early stage in their education realize the complexity of the practices in the teaching situations. They were in authentic situations in a teacher's working life and their experiences can, thus, be described as learning at a workplace (Illeris, 2017, p. 209). The students come to a workplace where qualified teachers are constantly learning by developing, evaluating and questioning their teaching procedures and the teacher students have the opportunity to become aware of this learning in working life. According to the ideas put forward by Lave and Wenger (1991), concrete situations influence the learning that occurs and at the same time has significance for activating the already existing results from previous learning. This learning can take place more or less by chance, come by itself, and be informal and incidental. Since this kind of learning tends to be narrow and lacking in theory (Illeris, 2017, p. 210), we may assume that the combination of learning in working life with theoretical studies provides the teacher students with valuable insights. In the study by Wenger et al. (2015), there are discussions about the fact that learning situations and learning communities provide the overall learning conditions and are parts of the so-called learning landscapes. By working with this combination of learning, the quality in teacher education can be secured and made more sustainable and prepare the students for their future career as described by Illeris $(2017$, p. 201, 238) “... the quality of learning is dependent on comprehension, assessments, interpretations and altogether what the learning can be used for in relevant and often unpredictable situations”. 


\section{Didactic Dilemmas}

Dilemmas are problems that do not have a rational solution. In this context, a broad definition and several concepts are used to define a dilemma, such as a problem, a difficulty or a problematic situation (Almqvist, Hamza, \& Olin, 2018, p. 15).

In descriptions of dilemmas, researchers use categories in order to organize the results in their studies. Pareja Roblin and Margalef (2013) use two categories of dilemmas in their investigation on university lecturers at a Spanish university working as an inquiry community. The first category is interpersonal dilemmas, which refer to tensions resulting from collaboration and interactions with other members from the community. The second category, intrapersonal dilemmas, are related to "the conflicts and tensions individual teachers experience in their daily practice as a consequence of the complex and uncertain nature of teaching" (Pareja Roblin \& Margalef, 2013, p. 19). The dilemmas concern issues such as curriculum, teaching strategies, student learning, the planning and implementation of cross-curricular activities, classroom management and teacherstudent interactions. One of the conclusions in this study is the possible interconnection between the interpersonal and intrapersonal dilemmas experienced by the teachers.

The different types of dilemmas that the teacher might face at school are described by Winchester (2009) by listing five categories of dilemmas and defining them as being characterized by (1) teaching and learning dilemmas, (2) emotional dilemmas, (3) practical social dilemmas, (4) moral dilemmas and (5) legal dilemmas. In these five categories of dilemmas, Winchester lists a number of strategies for the teacher to use. These strategies include, for instance, whether and how the teacher should prioritize the assistance and time to learners with difficulties, to the gifted learners or to the so-called ordinary learners.

The professional teacher is fully aware of the complexities in the teaching situations and that immediate and in some cases difficult decisions need to be taken. In addition, no matter what the decision is, there may always be some negative consequences of some kind that make this decision taking into challenges and dilemmas. What is central is that the context and, therefore, many didactic questions posed will have answers such as "it depends". Apart from these contextual factors, the individual teacher's ways of acting and handling in the teaching situation are decisive and, for that reason, we tend to think about teaching as something that is being characterized by the individual. At the same time, there is evidently often a general pattern how teaching procedures are carried out in various subjects. Didactic principles may then guide the teachers in their planning, actions and evaluations. One of these principles that directs the teacher is the aim of creating some interest among the learners, which then, in its turn, is influenced by the contextual factors (Bronäs \& Runebou, 2010, pp. 11-15).

Evidently, teacher students on practicum may experience other dilemmas than experienced teachers do. In addition, the experiences may be different from the beginning to the end of their school practice period. This trajectory is clearly described in a study on six teacher students in China completing a four-month practicum. The six students were faced with four dilemmas, namely: (1) tensions between classroom authority and caring, (2) acting as a member of the school community or as an outsider, (3) being an assistant or a real teacher, and (4) conflicting pedagogies with regard to different levels of the pupils' performance. The study describes the gradual development of teacher students as professional teachers (Deng et al., 2018). 
Focusing on dilemmas is useful not only in teacher education but also as part of teacher collaboration and in social interaction between teachers no matter what level in education. Working together in educational settings towards shared goals is part of a teacher's work and contributes to professional development.

\section{Ethical Dilemmas}

Dilemmas can concern ethical problems in the teaching practice. The ethical dilemma is defined as "an inner conversation with the self, concerning two or more available positions" (Shapira-Lishchinsky, 2011, p. 648). Five main categories of ethical dilemmas were used in a study of 50 teachers in 50 different secondary and high schools in Israel. The categories are (1) caring climate versus formal climate, (2) distributive justice versus school standards, (3) confidentiality versus school rules, (4) loyalty to colleagues versus school norms and (5) family agenda versus educational standards. The identified critical incidents reported by Shapira-Lishchinsky (2011) in these five categories provide a picture of the overall complexity of the teaching profession.

In a study on 100 teacher students in their final year of studies in New Zealand, the students' ethical dilemmas while on a seven-week practicum were in focus. Since dilemmas are strongly contextualized, it is of significance to instil confidence in the students' own moral compass. The students experienced four categories of dilemmas: (1) personal pedagogical beliefs versus school practice, (2) dealing with the challenging behavior of pupils versus having a safe learning environment, (3) cultural and religious sensitivity versus equal time and value to all children, and (4) fear of accusations of misconduct versus meeting the needs of all pupils. In this study, the conclusion is that at the early stages of teacher education, we need to discuss the contextual factors of ethical dilemmas and to understand that ethical dilemmas are common in the working life of all teachers (Davies \& Heyward, 2019).

Closely linked to ethical dilemmas is how to handle relationship boundaries between students and teachers. In a phenomenological study with 13 teachers using interviews, the interest was to find out how these teachers defined the relationship boundaries when dealing with emotions in the classroom. The results identified several categories of boundary dilemmas. The metaphor "the line" describes the boundary between useful involvement and becoming too involved. The teachers in the interviews highlighted that sharing too much personal information in the early years of teaching led to reflections on personal and emotional involvement boundaries, which were claimed to be important in order to avoid emotional overload (Aultman, Williams-Johnson, \& Schutz, 2009).

A central issue, which is relevant to include in the discussion about ethical dilemmas, is the fact of offering education that is common for all pupils. This dilemma includes questions such as what content, methods and values are to be given priority in the classroom (Gauthier, 2016). From an international perspective, it is worth considering that this issue of a common curriculum tends to be discussed irrespective of country or cultural context. Questions are raised considering what decisions the teacher has to take at a more general level regarding, for instance, values that should be highlighted and discussed.

Another related matter is the situation that school has a responsibility to contribute to pupils' well-being in their learning. The future role of teachers and educational institutions puts demand for adopting a more significant role in promoting the well-being of 
pupils by finding a balance between academic learning and emotional well-being. This recommendation is suggested based on the results from the MYWeB project (Stasulane, 2017). This demand for a balance may definitely create dilemmas for the teachers in their daily work. One of the means to improve the teacher education system is finding this balance by trying new methods in teacher education.

\section{Dilemmas Related to Specific Subjects}

Even though it is clear that didactic dilemmas concern overall didactic questions for the individual teacher, the characters of the dilemmas are often closely related to the teaching and learning of specific subjects. In what follows, there are examples of didactic dilemmas related to specific subjects in order to illustrate this phenomenon at a concrete level.

In the teaching of the mother tongue in primary schools, a dilemma includes how to make primary school pupils develop their reading comprehension. Another dilemma is rather related to the teaching of natural sciences but could also emerge in other subjects, namely, how to deal with the teaching of things we cannot observe, like gases in chemistry. Physical education is another subject with its own dilemmas, namely the occurrence of touches and body contacts. Generally, a dilemma can be regarded as how the teacher can make pupils at a primary school level actively participate in their own learning, and described in the literature to occur in mathematics. Finally, the teacher may identify dilemmas in subjects when there is demand for the content related to a planned national test. All in all, dilemmas put demand for teachers' professional considerations about what is good teaching not only generally but also specifically in various subjects (Almqvist et al., 2018).

When it comes to the teaching and learning of second foreign language at Swedish lower secondary schools, a described dilemma concerns the attitudes to second foreign language learning and teaching among adults and young people in Sweden. "There is a lack of motivation for second foreign language studies, and there is a relatively low degree of understanding of the advantages of second foreign language knowledge" (Bardel, Erickson, \& Österberg 2019). The foreign language teacher in this context has to deal with current ideas in society, which influence the motivation and thereby the learning and teaching in the classroom.

In interdisciplinary work at schools, which can be the case when working with sustainable development (Fedosejeva et al., 2018), particular dilemmas may emerge. In a study on the Erasmus+ partnership with teachers from five countries and pupils aged 12 to 16 years, the aim was to explore the potential tensions that occurred in interdisciplinary teaching. With the help of focus groups and participant observation, the results showed a variety of emerging tensions that caused didactic dilemmas. Four categories of the so-called meta-dilemmas were identified: a student-centered versus a teachercentered classroom, teaching towards educational goals versus other goals such as democratic and character-development goals, the teacher being objective or taking a stand and, finally, the issue of making adaptations for some pupils in oral discussions. The study points at the specific didactic dilemmas in lessons about complex and controversial issues (Rydberg, 2018). Another dimension that can be problematic and lead to dilemmas is to combine an integrative approach with national educational policies. Dimenäs and Alexandersson (2012) describe how crossing disciplinary borders of two 
subject traditions (water and justice) and relating them to sustainable development lead to dilemmas due to the tendency of encouraging and implementing a more closed and subject-centered discourse in Sweden. Issues of this kind in the teaching and learning procedures at primary schools that are related to sustainable development may lead to the types of dilemmas described above.

\section{Aim of the Study}

The aim of the study is to identify and describe the didactic dilemmas that teacher students experience in their work as a teacher candidate during their day once a week at a primary school. The research question is:

What didactic dilemmas do teacher students have in their work one day a week as teacher candidates at Swedish primary schools?

\section{Data Collected}

Seven teacher students applied for a position as a teacher candidate with one day a week at a primary school. Four of the students were students from the first year and three of them were students from the second year. They were all students of a four-year program of primary school teacher education for pupils aged 6 to 12 in the Swedish school system.

The seven teacher students submitted reports during their first semester when they had positions as teacher candidates. As shown in Table 1, there were four female and three male students in the group. The age of the students ranged from 19 to 53 years.

Table 1

Profiles of the Teacher Students Participating in the Data Collection

\begin{tabular}{cccc}
\hline Code & Gender & Teacher program & Age in 2019 \\
\hline S1 & male & Junior primary & 37 \\
\hline S2 & female & Senior primary & 41 \\
\hline S3 & female & Senior primary & 26 \\
\hline S4 & female & Junior primary & 19 \\
\hline S5 & female & Junior primary & 37 \\
\hline S6 & male & Senior primary & 22 \\
\hline S7 & male & Senior primary & 53 \\
\hline
\end{tabular}

The reports comprise 11 contributions submitted by seven students in the latter part of 2019. The texts altogether have a length of 4,227 words. The collection of the reports had follow-ups in the form of two seminar discussions on the students' reported data.

\section{Methodological Considerations}

The written reports were analyzed in order to identify themes by using a discourse analysis. Key words were identified and themes were worked out with the help of the didactic questions teachers are expected to have in mind. The analysis was, thus, based on the following didactic questions: (1) what - related to the content; (2) when - the 
order and the time allotted to the teaching and learning; (3) who - the learners' profiles and backgrounds; (4) how - the procedures and the methods selected for teaching and learning; and (5) why - the reasons and pedagogical ideas behind the selection of material and/or method. In addition, the didactic triangle was useful to have in mind in the analysis to see didactic relations that were most problematic in terms of Learner Material; Teacher - Learner; or Teacher - Material (Hopmann, 1997).

The seven teacher students all applied for positions as teacher candidates by the local authorities. They were of different gender, age and background. These factors were not taken into account; however, since the number of students was limited and generalizations were, thus, not possible based on these factors. The study should rather be regarded as a case study of seven interested and motivated teacher students who signed up to be at schools one day a week at an early stage in their teacher education. The focus in the present study is, thus, on the didactic dilemmas experienced irrespective of the teacher students' profiles.

\section{Results}

In the eleven contributions, it was possible to identify 29 dilemmas (two dilemmas were classified in two categories). The dilemmas were distributed in six categories as shown in Table 2.

Table 2

The Distribution of Dilemmas across the Six Categories

\begin{tabular}{lcc}
\multicolumn{1}{c}{ Categories of dilemmas } & Frequencies & $\begin{array}{c}\text { The number of } \\
\text { the dilemma }\end{array}$ \\
\hline $\begin{array}{l}\text { (A) Communication and classroom management } \\
\text { (B) The role and work as a teacher candidate in } \\
\text { relation to other teachers or staff }\end{array}$ & 3 & $3,10,23$ \\
\hline $\begin{array}{l}\text { (C) Methodological considerations of the planning } \\
\text { of teaching and learning }\end{array}$ & 7 & $1,8,14,15,21,24,26$ \\
\hline $\begin{array}{l}\text { (D) Pupils' background, attitudes, skills and } \\
\text { motivation }\end{array}$ & 6 & $7,9,11,16,18,25$ \\
\hline $\begin{array}{l}\text { (E) Subject content and the use of equipment } \\
\text { (F) Relationships with the pupils and conflicts, } \\
\text { group dynamics, pupils' well-being }\end{array}$ & 2 & $5,6,12,13,17,21,22,23$ \\
\hline Total & 8 & \\
\hline
\end{tabular}

As seen in Table 2, most of the dilemmas are related to three areas: $(C)$ methodological aspects of teaching and learning, (D) how to take into account the pupils' different backgrounds and (F) aspects of group dynamics and conflicts. In what follows, quotations are provided for illustration of the most common categories. (The quotations were translated from Swedish into English by the researcher himself.)

Category $(\mathrm{C})$ : “The dilemma that some pupils are quickly ready with what they should do, for instance, exercises or reading, and then you need to be prepared with an additional task/exercise with clear instructions." (Student 4)

Category $(\mathrm{D})$ : “The fact that there is a great range in the pupils' reading skills in Swedish influences the work in the classroom. This phenomenon is identified across all 
subjects and it is clear that some pupils need more time simply to understand instructions, short text passages or list of questions." (Student 3)

Category $(\mathrm{F})$ : “The practice of finding every day efficient solutions to common problems such as conflicts among pupils, motivating children to study and helping them concentrate, and comforting sad children." (Student 1)

\section{Analysis of the Results}

The results are from teacher students' experiences of dilemmas at schools at the first stages in their education. The dilemmas described show that the teacher students were studying the practice at schools and were obliged to use a didactic perspective in their decision-making when organizing what they experienced in a systematic way (Bronäs \& Runebou, 2010). These experiences are, at least partly, of another kind than those of educated and experienced teachers, which are to be taken into account in the analysis. The teacher students experienced real dilemmas regarding methods, pupils' different backgrounds and conflicts in the classroom. These dilemmas were difficult to solve and had competing alternatives (Flett \& Wallace, 2005) with no evident solutions and were occasions of learning at a workplace (Illeris, 2017). We can expect that the teacher students had the opportunity to discuss the dilemmas at their schools, which then developed their didactic competence (Tichá \& Hospesova, 2013). These practical experiences can be assumed valuable in their learning landscape (Wenger et al., 2015).

More specifically, the teacher students were concerned about finding a balance between the pupils' learning and their well-being as described by Stasulane (2017). This insight into a very concrete dilemma, and possibly a very common one for teachers at schools today, is a worthwhile example of the benefits of this project of the teacher candidates.

Dilemmas related to specific subjects were present in the collected data. The teacher students experienced dilemmas related to reading comprehension in the mother tongue and learning mathematics in primary school. As described by Almqvist et al. (2018), it is essential to make pupils at primary school develop their reading comprehension and difficulties turn up for the teacher when there are major differences in this skill among a group of children. It is also emphasized by Almqvist et al. (2018) that a dilemma, for instance, in mathematics, is to make pupils actively participate in their own learning. This dilemma was explicitly presented in the collected data.

\section{Conclusion}

The results show that teacher students at an early stage in their education can benefit from applying their theoretical knowledge in school. Working one day a week at school makes them experience didactic dilemmas of different kinds that are useful in their preparation for a professional career as schoolteachers. Teacher education at universities, and particularly at minor campuses, need to find sustainable ways to attract young people to programs of teacher education in order to secure sustainable education at schools with qualified teachers in more rural areas of the countries. Teacher education, thus, needs to be attractive and have applied studies in order to be of high quality and sustainable. 
The dilemmas expressed by the seven Swedish students during their one-day-a week practicum are similar in character to the ones described in long practicums by teacher students in different cultural contexts in previous studies. This implies that introductory periods of school practice for teacher students and with a limited time exposure lead to early learning of the challenges and dilemmas in the teaching profession. These experiences show that a minor campus can find a means of making sustainable teacher education in terms of combining theory and practice in an effective way (Salite, 2015). School practice introduced regularly and systematically at an early stage in teacher education could make it more sustainable by reducing stress and dropout among the teacher candidates. It remains to be seen whether this combination also leads to a more sustainable and stable teacher education at a minor campus in the Baltic Region. The phenomenon of didactic dilemmas experienced by student teachers in school practice are a research field that needs more attention in order to work for developing more sustainable teacher education.

\section{Acknowledgements}

Thanks go to the seven participating teacher students in the programs of lower and upper primary school at Uppsala University, Campus Gotland, for participating in the present study by generously sharing their experiences of didactic dilemmas at their weekly school practice.

The fact that Region Gotland financed and organized a system of teacher candidates at primary schools on the island of Gotland was crucial for this project. It is, therefore, of significance to thank the local authorities, the teachers and the headmasters at the schools involved for their participation.

\section{References}

Almqvist, J., Hamza, K., \& Olin, A. (Eds.) (2018). Undersöka och utveckla undervisning professionell utveckling av lärare [Investigate and develop teaching - professional development of teachers]. Lund: Studentlitteratur.

Aultman, L. P., Williams-Johnson, M. R., \& Schutz, P. A. (2009). Boundary dilemmas in teacher-student relationships: Struggling with "the line". Teaching and Teacher Education, 25(5), 636-646. doi: 10.1016/j.tate.2008.10.002

Bardel, C., Erickson, G., \& Österberg, R. (2019). Learning, teaching and assessment of second foreign languages in Swedish lower secondary school - dilemmas and prospects. Apples - Journal of Applied Language Studies, 13(1), 7-26. doi: 10.17011/ apples/urn.201903011687

Bronäs A., \& Runebou, N. (2010). Ämnesdidaktik [Subject didactics]. Stockholm: Norstedts.

Davies, M., \& Heyward, P. (2019). Between a hard place and a hard place: A study of ethical dilemmas experienced by student teachers while on practicum. British Educational Research Journal, 45(2), 372-387. doi: 10.1002/berj.3505

Deng, L., Zhu, G., Li, G., Xu, Z., Rutter, A., \& Rivera, H. (2018). Student teachers' emotions, dilemmas, and professional identity formation amid the teaching practicums. The Asia-Pacific Education Researcher, 27(6), 441-453. doi: 10.1007/ s40299-018-0404-3 
Dimenäs, J., \& Alexandersson, M. (2012). Crossing disciplinary borders: Perspectives on learning about sustainable development. Journal of Teacher Education for Sustainability, 14(1), 5-19. doi: https://doi.org/10.2478/v10099-012-0001-0

Fedosejeva, J., Boče, A., Romanova, M., Iliško, Dz., \& Ivanova, O. (2018). Education for sustainable development: The choice of pedagogical approaches and methods for the implementation of pedagogical tasks in the Anthropocene age. Journal of Teacher Education for Sustainability, 20(1), 157-179. https://doi.org/10.2478/jtes2018-0010

Flett, J. D., \& Wallace, J. (2005). Change dilemmas for curriculum leaders: Dealing with mandated change in schools. Journal of Curriculum \& Supervision, 20(3), $188-213$.

Gauthier, R.-F. (2016). Ce que l'école enseigne en commun: enjeux et difficultés d'un thème politique majeur. Revue internationale d'éducation de Sèvres [What school in common teaches: Challenges and difficulties in a major political debate]. International Review of Education of Sèvres, 73, 39-46. https://doi: 10.4000/ries.5593

Geng, G., Midford, R., \& Buckworth, J. (2015). Investigating the stress levels of early childhood, primary and secondary pre-service teachers during teaching practicum. Journal of Teacher Education for Sustainability, 17(1), 35-47. doi: https://doi.org/ 10.1515/jtes-2015-0003

Ghorbani, S., Jafari, S. E. M., \& Sharifian, F. (2018). Learning to be: Teachers' competences and practical solutions: A step towards sustainable development. Journal of Teacher Education for Sustainability, 20(1), 20-45. doi: 10.2478/jtes-2018-0002

Hopmann, S. (1999). Wolfgang Klafki och den tyska didaktiken [Wolfgang Klafki and the German didactics]. In (Ed.), Didaktik: teori, reflection och praktik [Didactics: Theory, reflection and practice]. Lund: Studentlitteratur.

Illeris, K. (2017). How we learn - learning and non-learning in school and beyond ( $2^{\text {nd }}$ ed.). London: Routledge.

Lave, J., \& Wenger, E. (1991). Situated learning: Legitimate peripheral participation. New York: Cambridge University Press.

Pareja Roblin, N., \& Margalef, L. (2013). Learning from dilemmas: Teacher professional development through collaborative action and reflection. Teachers and Teaching, 19(1), 18-32. doi: 10.1080/13540602.2013.744196

Rydberg, C. (2018). Didaktiska dilemman i undervisning utifrån sambällsdilemman [Didactic dilemmas in teaching with the perspective of societal dilemmas]. Licentiate Thesis, Malmö universitet.

Salite, I. (2015). Searching for sustainability in teacher education and educational research: Experiences from the Baltic and Black Sea Circle Consortium for educational research. Discourse and Communication for Sustainable Education, 6(1), 21-29.

Schoenfeld, A. H. (2012). Problematizing the didactic triangle. ZDM, 44(5), 587-599. doi: $10.1007 / \mathrm{s} 11858-012-0395-0$

Shapira-Lishchinsky, O. (2011). Teachers' critical incidents: Ethical dilemmas in teaching practice. Teaching and Teacher Education, 27(3), 648-656. doi:10.1016/j.tate. 2010.11.003

Stasulane, A. (2017). Factors determining children and young people's well-being at school. Journal of Teacher Education for Sustainability, 19(2), 165-179. doi: 10.1515/jtes-2017-0021 
Tichá, M., \& Hošpesová, A. (2013). Developing teachers’ subject didactic competence through problem posing. Educational Studies in Mathematics, 83(1), 133-143. doi: 10.1007/s10649-012-9455-1

Wenger, E., Fenton-O’Creevy, M., Hutchinson, S., Kubiak, C., \& Wenger-Trayner, B. (2015). Learning in landscapes of practice: Boundaries, identity, and knowledgeability in practice-based learning. Abingdon: Routledge.

Winchester, I. (2009). Educational dilemmas. The Journal of Educational Thought, $43(2), 89-91$.

Correspondence concerning this paper should be addressed to Stellan Sundh, Ph D, Assistant Professor, Uppsala University, Campus Gotland, Department of Education, SE-62163 Visby, Sweden. Email: stellan.sundh@edu.uu.se 